\title{
GROUP WORD TERMS IN THE TERMINOLOGY OF THE THEORY OF MECHANICS IN ALBANIAN AND ENGLISH
}

\author{
Gani PlLana \\ gani_pllana2012@hotmail.com \\ University of Prishtina "Hasan Prishtina", \\ Republic of Kosova \\ SADETE PlLANA \\ sadetepllana@hotmail.com \\ University of Prishtina "Hasan Prishtina", \\ Republic of Kosova
}

\begin{abstract}
As it is known, the terminology of any knowledge field as an independent system, as well as the terminology of mechanics consisting of nominating one-word and group word units (among which, particularly the latter phrase terms) make up nearly $70-80 \%$ of the overall terminological vocabulary. Looking at it from this point of view, all monosyllabic (one word) terms (word terms) would also be accepted as a basic vocabulary in the terminology of mechanics. This can be justified more so by the fact that almost every word term serves as the foundation for the construction of numerous group word terms that mark concepts which have spread out into numerous branches. These having been introduced through a variety of many different interrelations, like gender / type, whole / part etc.
\end{abstract}

Key words: term, group word (phrase), terminology, theory of mechanics.

\section{INTRODUCTION}

With the overall development of sciences and technologies on an international and national level, the knowledge fields have multiplied and become so differentiated, so much so that to supplement them with terms meant it could be done only by using foreign terms. And these flooded in in large numbers, particularly into textbooks as well as in technical documentations, in all types of manuals and all the way to Lecturing.

Over the course of time foreign words have entered the Albanian language with their specific features in two main parts of the vocabulary: in the general lexicon and in the terminological one.

Sometimes terms enter into the composition of idioms or stable strings of words; in this case the term contains as it were the nucleus of the phrase and gives it a perception, though separate from the phrase may probably not be comprehended even by the one using it. 


\section{PHRASAL TERMS IN BOTH LANGUAGES}

Thus from a quick shift of a terminological dictionary, though not of a narrow field but a wide one (Academy of Sciences of Albania, 2002); one can observe that, for example with the term lëvizje (motion) we meet 27 phrase terms in both languages, like lëvizje rrafshore (plane motion), lëvizje shtjellore (vortex motion), lëvizje tranlative (translational motion), etc. Likewise can be said for hallkë, rrip, sustë, rrotë etc.; with hallkë (link) there are 6 compound word, with rrip (belt)-12, with sustë (spring)-14, with rrotë (wheel)-39. In the vocabulary of a narrow field (like a subfield or branch of Mechanics, as, for example. "Mechanisms Dictionary" (English-German) (Buckch, 1976). with the term gear (Engl.) there are 148 compound words. We my look at the Base Terms of this terminology from two points of view: as a collective vocabulary, which could be confined within the core subfields, which further narrows also the amount of such terms (here this would include the subfield lexicon such as Theory of Mechanics, Applied Mechanics, or any other material resistance); and as a lexicon that consists of terminological units of every subfield (be those particular ones, like the subfields of automobile, of thermo-technics, of agricultural machines), but which in themselves are the very basic terms of these subfields. From the perspective of the form they are term words and mark key concepts such as, e.g., piston, crank, engine, differential, (from aut.) Alb: avull, turbinë, gjenerator, in Engl: steam, turbine, generator (term. tech.). It may be underlined that their presence within the phrase terms does enhance their value as basic terms, as may be brought as an example pompë and pompë ajri (pump and air pump), pompë e lëndës djegëse (pump and fuel pump), i.e. finding around 44 of these in the above vocabulary.

On the other hand, compound stems of groupword terms will also be introduced into the quality of the basic vocabulary, when these, from a word forming (term forming) perspective connect to the system with such terms, as well as when in themselves they mark specific concepts related to the field (subfield) in question. The specific character of the conceptual content that they express, as well as the connection into the system with the monosyllabic terms by which they become motivated, are two fundamental traits which motivate their distinctiveness as a basic terminology lexicon. As can be compared alongside aks and aksor (aksial) (Engl. axis and axial), alongside ingranim and ingranoj (Engl. meshing and mesh $(=$ to mesh)), alongside aks and aksialisht (Engl. axis and axially). This means that the component elements of phrase terms will also be accepted as base terms, when they will appear as terms in other forms of speech as well, except the noun which means, as adjectives (aksor-e, kinematik-e, rrëshqitës-e; in Engl:: axial, kinematic, sliding), as verbs (ingranohet, çiftëzohet, rrotullohet; in Engl.: (to) mesh, (to) couple, (to) rotate)) as adverbs (aksialisht, kinematikisht; in Engl.: axially, kinematically). By not getting into the debating part of the problem, which is not the subject of this paper, we will accept as terms not only nominating terminological units expressed by nouns and compound words with a nominal base ${ }^{1}$, but also the units expressed

Në fjalorët e terminologjisë (të serisë), botuar nga IGJL, nuk është mbajtur qëndrim i prerë për këtë problem. Në fjalorët e parë (rreth 10) janë përfaqësuar në ta edhe termat mbiemra, rrallë folje 
from other parts of speech, especially when they express the specificity of the field and relate to the word forming with the word term as çift and çiftëzohet-i çiftëzuar; aks and aksial-aksialisht (couple and (to) couple-coupled; axis-axial-axially).

\section{OBSERVATION ON THE FORMATION OF TERMS}

The observation of terms as units also that appear in other parts of speech has particular relevance for discovering the formation mechanism of terms, because, on one hand, monosyllabic terms themselves have a certain word-forming composition, like rrëshqitje (from rrëshqit (sliding (as adjective) from slide (as verb)), but they themselves serve for the formation of the many compound words, as there are in their composition, like shkarës-e in lëvizje shkarëse, rrotullues-e in hallkë rrotulluese, as in Engl.: sliding (as adjective) in sliding motion, rotating (as adjective) in rotating link.

The treatment of these Forms of expressing concepts (i.e., adjectives, verbs and adverbs) takes a practical value to reflect these in the relevant terminology dictionaries. Their involvement is important to highlight the systemic nature of the terminology on the level of the Form, like, alongside ingranim and ingranohet, alongside përpunim and përpunoj-i përpunuar-përpunues-e (In Engl.: machining-machined-machining (as adjectives)). In the frame of terminology research, this is an overview of the terms from a linguistic point of view. In this case, the conceptual point of view (which belongs to the terminologist and mainly to the specialist in the field) combines with the linguistic perspective which belongs to the linguist, who will see the term on the level of the word. In this case, the component parts of compound words can also be treated as independent units. Thus, for example, on the one hand, makinë përpunuese as a term in itself, but also përpunues-e as an independent unit, which, either may be presented in a proper terminological dictionary, along with providing other units in it, single-worded and compound worded, or you can create another type of terminological dictionary, where on the basis of the reflected forms in it be single-worded units, represented not only by nominal terms, but also adjective, verb, and adverb terms.

Surely these units, to obtain the right to be entered in such a type of vocabulary, must connect to the word forming (term-forming) system either with the noun term or with each other, such as termodinamik-e/termodinamikisht that connect with termodinamikë, ingranoj(ndërdhëmbëzoj). The presentation of the scientific and technical information of the field in question may not reflect the complete systemic links between concepts (which as such appear in phrase terms, as, not only translativ-e (translational), but lëvizje translative (translational motion), zhvendosje translative (trans-

a ndajfolje (Fj. mat. 8: mekanik-e dhe mekanikisht), kurse në fjalorët e mëvonshëm janë pasqyruar termat emra dhe me bazë emërore. Tek Fjalori i Vysterit, që pranohet edhe si fjalor pilot, takojmë aty këtu edhe terma emra si (to) work, (to) machine, (to) tool, por jo terma mbiemra dhe ndajfolje. (In the terminology dictionaries (of the series), published by IGJL, there has not been kept a strict approach for this problem. In the first dictionaries (about 10) are represented also adjective terms, rarely verb or adverb (Fj. mat. 8: mekanik-e and mekanikisht), whereas in subsequent dictionaries are reflected noun terms and terms with a noun base. In Vyster's vocabulary, which is also accepted as a pilot vocabulary, here and there we come across also on noun terms like (to) work, (to) machine, (to) tool, but not adjective and adverb terms.) 
lational displacement), whereas by this method a more condensed and more economic information is provided. This type of vocabulary surely becomes a secondary (additional) one compared to a proper terminological dictionary, in which through providing the complete connectivity system of concepts through word terms and phrase terms, a scientific and technical information is presented in a comprehensive way. This type of dictionary with the representation of the concepts of other parts of speech as well, with adjectives, verbs, adverbs, which connect to the system with noun terms, facilitates the work of the translators of texts of the relevant field by making it easier to find the equivalent in the foreign language, as well as helping foreign students to learn the foreign terminology (e.g. Albanian students with textbooks for terminology of a related field). Seen from this point of view, these types of dictionaries may have a terminological-learning orientation, where the term is estimated more linguistically, than conceptually, i.e. more by form than by content.

Below we make a modular presentation of a terminological-educational type of dictionary in both languages, by comparing it with a genuine traditional terminology dictionary.

a) In Albanian

The Model of the traditional

terminological Vocabulary

The Model of the terminological

learning textbook Vocabulary learning textbook (where the whole terminological conceptual system is reflected)

hallkë

hallkë udhëzuese

hallë e udhëzuar

hallkë lëvizëse

hallkë e lëvizshme

hallkë rrotulluese

hallkë e rrotullueshme

hallkë e zinxhirit kinematik

zinxhir

zinxhir kinematik

zinxhir traktori

lëvizje

lëvizje rrotulluese

lëvizje zhvendosese

lëvizje translative

zhvendosje

zhvendosje translative

mekanizëm (+ 148 togflalësha)

mekanizëm katërhallkësh

mekanizëm katërhallkësh $i$ çernieruar

hallk/ë-a
udhëzues-e
i/e udhëzuar
lëvizës-e
i/e lëvizsh/ëm-me
rrotullues-e
i/e rrotulluesh/ëm-me
lëvizj/e-a
lëviz
rrotullim-i
rrotulloj
rrotullohet
kinematik-e
zinxhir-i
traktor-i
zhvendosj/e-a
zhvendosës-e
translativ-e
mekaniz/ëm-mi
katëhallkësh-e
i/e çernieruar
çernieroj (çernierohet)




\section{b) In English}

link

driving link

driven link

moving link

movable link

rotating link

rotary link

rotary link

link of kinematic chain

chain

kinematic chain

traktor chain

motion

rotary motion

displacing motion

translational motion

displacement

translational displacement

mechanism (+ 140 phrase terms)

four-bar mechanism

hingel four-bar mechanism link

driving

driven

moving

movable

(to) move

rotating

rotary

(to) rotate

kinematic

chain

traktor

motion

displacing

displacement

(to) displace

translational

mechanism

four-bar (-) (mechanism)

hinged

(to) hinge

(to be hinged)

\section{CONCLUSION}

Regarding the use of basic terms in the field of mechanics it can be said that they find their own place in the fundamental subfields, which materialize in such formative educational subjects especially in the two most primary ones as Theory of Mechanics and Applied Mechanics, as well as other subjects close to them.

The comparison of technical-scientific terms of Albanian language with other languages, especially with the English language, shows that in the Albanian language we can notice the synthesizing ability of the means of expression (see: gas separator (Engl.) = gazveçues, bosht motori $=$ bosht motorik), as well as the degradative capacity of the means of expression (bosht me bërryla, bulon pa kokë). In terms of the skills of word formation the Albanian language owns the agility of analytic languages (e.g. English, French), as well as the potency of synthetic languages (e.g. Russian language). This gives it the ability to fulfill its linguistic needs for new words with its own means for word formation. These potential skills will in future become more and more implemented, by being stimulated also by the development of science and technology in our country, by the discovery of new phenomena, by the creation of various objects, as well as by vast realizations of the technical-scientific revolution. 


\section{REFERENCES}

Arntz, R., \& Picht, H. (2004). Einführung in die Terminologiearbeit [Introduction to terminology work]. Vol 2. Hildesheim, Zürich, New York: Georg Olmes Verlag.

Beer, F. (2004). Vector Mechanics for Engineers Statics. New York: McGraw-Hill.

Duro, A. (2003). Sistemet terminologjike dhe dysorët terminologjikë në rrafshin e fjalëformimit të gjuhës shqipe të përqasur edhe me italishten, anglishten dhe rusishten [Terminology systems and terminology binaries on the plane of word formation of the Albanian language, compared also with Italian, English and Russian]. Tirana: Dissertation theme.

Duro, A. (2009). Termi dhe fjala në giuhën shqipe [Term and word in Albanian]. Tirana: Fan Noli. Academy of Sciences of Albania (2002). Fjalor i termave themelorë të mekanikës [Dictionary of basic terms of mechanics]. Tiranë: Shkenca.

Gaçe, Th. (1983). Mekanika teorike (Vol. 1, 2, 3) [Theory of Mechanics]. Tirana: University of Tirana.

Jagxhiu, F. (1976). Përmbledhje detyrash të zgjidhura nga Mekanika I (Statika) [Collection of solved problems of Mechanics I (Statics)]. Prishtina: ETMM of the Socialist Autonomous Province of Kosova.

Kurti, S., Hysa, R., \& Kurti, Ç. (1991). Fjalor politeknik anglisht-shqip [Polytechnic Dictionary EnglishAlbanian].Tirana: Kombinati Poligrafik-Shtypshkronja e Re.

Leka, F. (1983). Udhëzues për përpunimin e terminologiisë tekniko-shkencore. [Guide for the processing of technical and scientific terminology]. Tirana: Institute of Linguistics and Literature.

Norton, L. R. (2004). Design of Machinery. New York: McGraw-Hill.

Picht, H. (1985). Terminology: An Introduction. Kopenhagen: University of Surrey, Department of Linguistic and International Studies.

Pllana, G., \& Pllana, S. (2012). A conceptual connections on a word and term level in the terminology of Theoretical Mechanics (in Albanian and English)."Trans\&Motoauto"12 20 th International scientific and technical Conference on transport, road-building, agricultural, hoisting $\mathcal{E}$ hauling and military technics and technologies. 27.-29.06.2012, Varna, Bullgari, p. 3-4.

Pllana, S., \& Pllana, G. (2012). Rruga semantike e ndërtimit të terminologjisë së mekanikës teorike në shqip dhe anglisht. [Semantic path of the structure of the terminology of theoretical mechanics in Albanian and English]. International Conference challenges to studies in english language, 1-2 June 2012, University of Tirana, FGJH Departament of English Language. Tirana: University of Tirana (not published yet).

Pllana, S., \& Pllana, G. (2012). Marrëdhëniet e leksikut terminologjik dhe joterminologik në lidhje me informacionin shkencor-teknik në fushën e mekanikës teorike [Relationship of terminological lexic on terminology and not about scientific and technical information in the field of theoretical mechanics] Wissenschaftliche Konferenz, Literatur, Landeskunde und Komparatistik, Fremdsprachen-fakultät der Universität Tirana, June, 29 ${ }^{\text {th }}, 2012$, Tirana (not published yet).

Pllana. S. (2003). Standardizimi i terminologiisë [The standardization of terminology].

TEKNIKA - Revistë profesionale dhe shkencore për teori dhe praktikë, I(2), 20-26.

Wüster, E. (1991). Einführung in die allgemeine Terminologielehre und terminologische Lexikographie [Introduction to the general theory of terminology and terminological lexicography]. ( $3^{\text {rd }}$ ed.). Bonn: Romanistischer Verlag. 